\title{
EVALUATION OF OUTCOMES OF PRIMARY PSEUDOPHAKIC RETINAL DETACHMENT SURGERY
}

\author{
PRIMER PSÖDOFAKIK RETINA DEKOLMANI CERRAHISI SONUÇLARININ \\ DEĞERLENDIRILMESI
}

\section{Zeynep YILMAZABDURRAHMANOĞLU ${ }^{* *}$ (D), Kemal Turgay ÖZBILEN²* (D), Mehmet Selim KOCABORA ${ }^{3}$ (D), Osman ÇEKiÇ ${ }^{4}$ (D)}

1Bagcilar Training and Research Hospital, Ophthalmology Clinic, Istanbul, Turkey

${ }^{2}$ Istanbul University, Istanbul Faculty of Medicine, Department of Ophthalmology, Istanbul, Turkey

${ }^{3}$ Istanbul Medipol University, Faculty of Medicine, Department of Ophthalmology Istanbul, Turkey

${ }^{4}$ Marmara University, Faculty of Medicine, Department of Ophthalmology Istanbul, Turkey

ORCID IDs of the authors: Z.Y. 0000-0002-6075-8513; K.T.Ö. 0000-0002-0234-3803; M.S.K. 0000-0001-5335-3860;

O.Ç. 0000-0003-0911-8649

Cite this article as: Yilmazabdurrahmanoglu Z, Ozbilen, KT, Kocabora MS, Cekic O. Evaluation of outcomes of primary pseudophakic retinal detachment surgery. J Ist Faculty Med 2021;84(4):488-94. doi: 10.26650/IUITFD.2021.836991

\section{ABSTRACT}

Objective: To evaluate the results of pars plana vitrectomy (PPV) alone and combined with circumferential scleral buckling (CSB) surgeries for aphakic or pseudophakic rhegmatogenous retinal detachment (RRD)

Materials and Methods: Thirty-seven eyes of 37 patients who underwent PPV (20 and 23 Gauge) alone or PPV combined with CSB due to pseudophakic or aphakic primary RRD were included in the study. Postoperative anatomical success (AS) and functional success (FS) were evaluated. The AS was defined as a completely flattened retina without any subretinal fluids after the removal of the silicone oil tamponade, if used. The FS was defined as two or more decimal improvements in the logMAR equivalent of Snellen visual acuity.

Results: The mean age of the patients was $62.43 \pm 11.40$ (32-80) years, 21 (56.8\%) patients were male, and $16(43.2 \%)$ were female. The mean follow-up time was $21.35 \pm 16.86$ (6-84) months. PPV combined with CSB were performed in 23 patients. AS was found to be $86.5 \%$ (32/37), FS was $49.9 \%$ (17/37). No statistically significant difference was observed in both AS and FS between the groups according to preoperative PVR presence (AS- $p=0.61$, $F S-p=0.14$ ), preoperative macular involvement ( $A S-p=0.98$, $F S-p=0.36$ ), whether PPV combined with CSB (AS- $p=0.97$, FS$p=0.29)$, and the type of tamponade ( $p>0.05$ in all).

Conclusion: PPV with or without CSB is safe and effective in cases with primary pseudophakic retinal detachment and achieves good AS without being affected by the presence of PVR or macular involvement. However, functional success may not always follow.

Keywords: Pseudophakic retinal detachment, pars plana vitrectomy, circumferential scleral buckling

\section{ÖZET}

Amaç: Afakik veya psödofakik regmatojen retina dekolman (RRD) için tek başına pars plana vitrektomi (PPV) ve çevresel skleral çökertme (ÇSÇ) ile kombine ameliyatların sonuçlarını değerlendirmek.

Gereç ve Yöntem: Psödofakik veya afakik primer RRD'ye nedeniyle tek başına veya ÇSÇ ile kombine PPV (20 ve 23 Gauge) uygulanan 37 hastanın 37 gözü çalışmaya dahil edildi. Postoperatif anatomik başarı $(A B)$ ve fonksiyonel başarı $(F B)$ değerlendirildi. $A B$, eğer kullanılmışsa silikon yağı tamponadının çıkarılmasından sonra hiç subretinal sıvının olmadığı tamamen yatışmış retina olarak tanımlandı. Ayrıca FB, Snellen görme keskinliğinin logMAR eşdeğerinde iki veya daha fazla ondalık artış olarak tanımlandı.

Bulgular: Hastaların ortalama yaşı $62,43 \pm 11,40$ (32-80) yıl, 21'i $(\% 56,8)$ erkek, 16'sı $(\% 43,2)$ kadındı. Ortalama takip süresi $21,35 \pm 16,86$ (6-84) aydı. 23 hastaya ÇSÇ ile kombine PPV uyguland.. AB \%86,5 (32/37), FB \%49,9 (17/37) olarak bulundu. Hem AB ile hem de FB ile; preoperatif PVR varlı̆̆ $(A B-p=0,61, F B-p=0,14)$, preoperartif maküla tutulumu (AB- $p=0,98, F B-p=0,36)$, PPV'nin ÇSÇ ile kombine olup olmaması ( $A B-p=0,97, F B-p=0,29)$, ve kullanılan tamponad tipi (tümü $p>0,05$ ) gibi durumlara göre oluşturulan gruplar arasında istatistiksel olarak anlamlı bir fark gözlenmedi.

Sonuç: Primer psödofakik retina dekolmanı olan olgularda PPV yalnız veya ÇSÇ ile kombine olarak uygulandığında, maküla tutulumundan veya PVR varlığından etkilenmeden iyi $A B$ ulaşmak için etkili ve güvenlidir. Bununla birlikte, fonksiyonel başarı her zaman eşlik etmeyebilir.

Anahtar Kelimeler: Psödofakik retina dekolmanı, pars plana vitrektomi, çevresel skleral çökertme

*Both authors contributed equally

Corresponding author/illetişim kurulacak yazar: turgay.ozbilen@istanbul.edu.tr

Submitted/Başvuru: 07.12.2020 • Revision Requested/Revizyon Talebi: 30.01.2021 •

Last Revision Received/Son Revizyon: 23.02.2021 • Accepted/Kabul: 23.02.2021 • Published Online/Online Yayın: 27.08 .2021 


\section{INTRODUCTION}

Retinal detachment (RD) is a rare but severe complication of cataract surgery and, if left untreated, results in vision loss of the affected eye. Some researchers have pointed out that about $50 \%$ of RD develops within one year of cataract extraction surgery $(1,2)$. The incidence of RD after intracapsular cataract extraction surgery (ICCE) is $0.98-3.6 \%, 0.33-1.7 \%$ after extracapsular cataract extraction surgery (ECCE), and $1-1.17 \%$ after phacoemulsification. This incidence is eight times more than the normal population $(3,4)$. With the increase in the number of cataract surgeries performed in the last 20 years, the incidence of aphakic and pseudophakic rhegmatogenous RD (RRD) has also increased. Although it is known that with current phacoemulsification surgery, complications during and after surgery are reduced, retinal detachment is a complication that remains relevant, as it significantly reduces the patient's visual expectations. The number of people undergoing cataract surgery accounted for about 3\% of the overall population, while $40 \%$ of patients with RRD had a history of previous cataract surgery. It is believed that removing the natural lens accelerates vitreous liquefaction, which causes premature posterior vitreous detachment and increases the risk of RD (2-4). The condition of the lens capsule also determines the vitreous liquefaction amounts. It is known that posterior lens capsule perforation during surgery and neodymium yttrium-aluminum-garnet ( $\mathrm{Nd}$ YAG) laser capsulotomy significantly increases RD incidence (5). Some potential risk factors are influential in $\mathrm{RD}$ development after cataract surgery. These factors were indicated as preoperative predisposing factors (myopia, lattice degeneration), intraoperative complications (posterior capsular rupture with or without vitreous loss), and postoperative factors (i.e., capsulotomy, vitreous hemorrhage, trauma) that are unrelated to the surgical procedure.

Evaluating fundus' appearance when examining pseudophakic RD patients may be tricky with opacification, reflections, and weak mydriasis. Circumferential scleral buckling (CSB), pneumatic retinopexy, primary pars plana vitrectomy (PPV) alone or with CSB are surgical options used to treat pseudophakic RD (6-8). The use of internal tamponades with PPV increases the success of this surgery (9). Although anatomical success rates are high after vitreoretinal surgeries, good visual outcomes are not always achieved as expected (10).

This study examined the clinical findings of primary RD in patients who developed RD after cataract extraction and underwent vitreoretinal surgeries in our clinic. Risk factors, surgery techniques and its results, and prognosis were evaluated.

\section{MATERIALS AND METHODS}

Approval was obtained from the Ethics Committee of Bezm-i Alem University Faculty of Medicine for this retrospective study. Informed consent forms were obtained from all patients in the study. The study was carried out in accordance with the tenets of the Helsinki Declaration.

Thirty-seven eyes of 37 patients who had been diagnosed with primary pseudophakic or aphakic RRD and had undergone PPV [20 or 23 Gauge (G)] with or without CSB between 2004 and 2011 were recruited to the study. This study evaluated demographic data, history of systemic and eye diseases, presence of myopia, time frame from cataract surgery to RD development, preoperative best-corrected visual acuity (BCVA), intraocular pressure (IOP), intraocular lens (IOL) condition, lens capsule integrity, and the presence of Nd-YAG laser capsulotomy, the condition of the retinal tears and detachment, the presence of macular involvement and proliferative vitreoretinopathy (PVR) were determined. Perioperative data [i.e., performing CSB and relaxing retinotomy-retinectomy, type of intraocular tamponade (IOT), complications], and postoperative data [BCVA, IOP, recurrence, anatomical success (AS), functional success (FS), and complications].

\section{Exclusion criteria}

Patients who underwent surgery due to recurrent detachment, underwent only scleral procedures without PPV, or were followed-up for less than six months were excluded.

\section{Surgical technique}

Standard PPV was performed, as under the wide-angle imaging systems, $20 \mathrm{G}$ or $23 \mathrm{G}$ (with trocar, transconjunctival) conventional three PPV ports were created. In the presence of advanced stage PVR, inferior retinal tears, or multiple tears in different quadrants, CSB was performed in the same session. ACCURUS $®$ Surgical System (Alcon, Fort Worth, Texas, USA) was used for vitrectomy. Standard surgical procedures were performed. Triamcinolone was used for visualizing posterior hyaloid and membranes. The vitreous base was shaved with indentation. Retinotomy/retinectomy was made when necessary. Sclerotomies were closed with 7.0 polyglactin sutures. As IOT, either 1000 cst silicone oil, 13\% C3F8 gas, 18\% SF6 or pure air were used to fill the entire vitreous cavity. If CSB was to be performed in the same session, limbal $360^{\circ}$ peritomy was performed on the conjunctiva. A number 240 band was passed under the rectus muscles, and was sutured $13 \mathrm{~mm}$ away from the limbus with 5.0 ethibond in 4 quadrants. The tightening of the band was done after PPV. Conjunctiva was closed with 8.0 polyglactin sutures. After the surgery, rest in the appropriate position was recommended. In postoperative care, Tobramycin eye drops (four times a day for ten days), prednisolone acetate 1\% drops (six times a day, tapered after one week and dis- 
Table 1: Demographic and characteristic data of the patients

\begin{tabular}{ll}
\hline Variables & Results \\
Male/Female- $n(\%)$ & $21(56.8 \%) / 16(43.2 \%)$ \\
Mean age- (year) & $62.43 \pm 11.40(32-80)$ \\
Mean follow-up (months) & $21.35 \pm 16.86(6-84)$ \\
Duration after cataract surgery (months) & $15.54 \pm 17.24(3-72)$ \\
PPV alone/PPV with CSB- n (\%) & $23(62.2 \%) / 14(37.8 \%)$ \\
PPV 20G/PPV 23G- $n$ (\%) & $19(51.4 \%) / 18(48.6 \%)$ \\
Type of cataract surgery (Phaco vs ECCE)- $n$ (\%) & $36(97.3 \%) / 1(2.7 \%)$ \\
Preoperative lens status (pseudophakic/aphakic)- n (\%) & $36(97.3 \%) / 1(2.7 \%)$ \\
IOL localization (bag/sulcus/AC)- n (\%) & $28(75.7 \%) / 5(13.5 \%) / 3(8.1 \%)$ \\
\hline
\end{tabular}

PPV: Pars plana vitrectomy, G: Gauge, Phaco: Phacoemulsification, ECCE: Extracapsular cataract extraction, IOL: Intraocular lens, AC: Anterior chamber

continued at the end of the one month) were prescribed. Antiglaucomatous drops were used if needed.

A detailed ophthalmological examination on the postoperative first day, first week, first, third, sixth months, and the following every six months were performed on all patients. BCVA values were measured with Snellen charts and converted into logMAR. The complications evaluated were corneal edema or opacity, hypotony (IOP $\leq 5 \mathrm{mmHg})$, elevated IOP ( $\geq 22 \mathrm{mmHg}$ ), fibrin formation, hyphemia, or vitreous hemorrhages. The surgeries performed between the study groups were compared in terms of AS, FS, BCVA, and complications. The AS was defined as a complete flattened retina without any SRF after removing the silicone oil (if used) in the final visit. Cases with two or more decimal improvements in the logMAR equivalent of Snellen BCVA were considered as FS.

The SPSS (Version 21, IBM Corp. Armonk, NY: USA) software statistic program was used for statistical analysis. The Wilcoxon Signed Ranks Test was used to compare descriptive statistics and the parameters that did not show normal distribution in the comparison of quantitative data. Fisher's Exact test and Chi-Square test was used to compare qualitative data. Pearson correlation analysis was used in correlation analyses. Statistically, significance was accepted as $p<0.05$.

\section{RESULTS}

Of the 37 patients included in the study, almost all had reduced vision at various levels at the time of admission. Photopsy-entopsy history was present in $6(16.2 \%)$ cases, and $6(16.2 \%)$ cases had a history of suspected head or ocular trauma.

High IOP was detected in 2 (5.4\%) patients in preoperative examination. Five of the patients $(13.5 \%)$ had a history of high myopia. Laser photocoagulation had been performed on two patients (5.4\%) for retinal tears before the surgery. In 9 (24.3\%) patients, there was a posterior lens capsule rupture and anterior vitrectomy history. A $\mathrm{Nd}$-YAG laser capsulotomy history was also in 1 (2.7\%) three months before RD. Three patients (8.1\%) who had anterior chamber I OL had a peripheral iridectomy. Demographic data and characteristic distributions of patients a re summarized in Table 1.

Preoperative PVR was present in 10 (27.0\%) patients, and PPV with CSB was performed on seven of these PVR cases. Posterior vitreous detachment (PVD) in 11 (29.7\%), prominent inflammatory reaction in $7(18.9 \%)$, and vitreous hemorrhage $(\mathrm{VH})$ were present in $2(5.4 \%)$ cases. Single retinal tears were detected in 23 patients and multiple retinal tears in 14 patients. The characteristics of retinal tears and RD are summarized in Table 2.

Table 2: Retinal tears and retinal detachment features

n (\%)

\section{Numbers of retinal tear}

Multiple $(3.3 \pm 1.1)^{*}$

Single

\section{Localization of retinal tears}

Superior quadrants

Inferior quadrants

Both superior \& inferior quadrants

$20(54.1 \%)$

\section{Involvement of retinal detachment}

Superior quadrants

Inferior quadrants

Both superior \& inferior quadrants

$20(54.1 \%)$

*: The average of only the multiple retinal tears patients 
Table 3: Change of mean BCVAs over time

\begin{tabular}{|c|c|c|c|}
\hline BCVA (logMAR) & Mean \pm SD & $(\min -\max )$ & $p^{*}$ \\
\hline Preop & $2.41 \pm 1.01$ & $(0.15-3.10)$ & \\
\hline postop $1^{\text {st }}$ week & $1.85 \pm 0.83$ & $(0.40-3.10)$ & $0.035^{*}$ \\
\hline postop $1^{\text {st }}$ months & $1.55 \pm 0.94$ & $(0.30-3.10)$ & $0.001^{* *}$ \\
\hline postop $3^{\text {rd }}$ months & $1.42 \pm 0.76$ & $(0.22-3.10)$ & $0.001^{* *}$ \\
\hline postop $6^{\text {th }}$ months & $1.38 \pm 0.77$ & $(0.22-3.10)$ & $0.001 * *$ \\
\hline postop final examination & $1.21 \pm 0.85$ & $(0.0-3.10)$ & $0.001 * \star$ \\
\hline
\end{tabular}

*Wilcoxon Signed Ranks test, between preoperative mean values and postoperative mean values, preop: preoperative, postop: postoperative, ${ }^{\star *}: \mathrm{p}<0.001$, BCVA: Best corrected visual acuity

In $75.6 \%$ of the patients, the final visit's BCVA values improved compared to the postoperative BCVA values. Significantly, the mean BCVA at all of the postoperative visits was better compared to the preoperative mean. The BCVA data before and after the surgery are summarized in Table 3.

The mean preoperative IOP was $13.04 \pm 4.11(6-30) \mathrm{mmHg}$. Although, in the postoperative first week, the mean IOP increased to $14.58 \pm 5.32 \mathrm{~mm} \mathrm{Hg}$, this increase was insignificant ( $p>0.05)$. However, in cases using an intraocular gas tamponade, a significant increase in IOP was observed. In the postoperative first month, the mean IOP was $17.04 \pm 7.94 \mathrm{mmHg}$, and in the sixth month, it was $15.78 \pm 5.12 \mathrm{mmHg}$; both were significantly high compared to the preoperative mean (both $p<0.05$ ). A high IOP was present in 7 (18.9\%) patients during the postoperative period. Cyclophotocoagulation was performed in a patient whose IOP was not controlled despite all medical treatments. IOP control was achieved in all patients after the sixth month. The final visit mean IOP was $13.62 \pm 4.97 \mathrm{mmHg}$, with no significant difference between the preoperative mean ( $p>0.05)$.

In postoperative first day examinations, corneal epithelial defects were observed in four patients (10.8\%), and corneal edema in $3(8.1 \%)$ patients. All epithelial defects healed within the first week; even so, epithelial irregularity was prolonged until the third month in two patients. Prolonged corneal edema was observed in two patients but disappeared at the first-month examination.

Anterior chamber IOL was removed in 2 (5.4\%) patients with anterior PVR whose vitreous base could not be shaved and visualized adequately. Relaxing retinotomy/retinectomy was performed in six of 10 PVR $(+)$ cases. Drainage retinotomy was performed on three cases (8.1\%). Two (5.4\%) patients developed a limited amount of suprachoroidal hemorrhage as intraoperative complications.

Silicone oil extraction was performed in the postoperative period, through the anterior chamber from the
Table 4: Distribution of intraocular tamponade used intraoperatively

\begin{tabular}{lcc}
\hline Tamponade & $\mathbf{n}$ & $\%$ \\
$\mathrm{C}_{3} \mathrm{~F}_{8}$ & 4 & $10.8 \%$ \\
Air & 1 & $2.7 \%$ \\
$\mathrm{SF}_{6}$ & 6 & $16.2 \%$ \\
Silicone oil & 26 & $70.3 \%$ \\
\hline
\end{tabular}

aphakic eye and the pars plana in the pseudophakic eyes. Silicone oil was not removed due to the lack of postoperative light projection in one patient. During the follow-up, 4 (15.4\%) of the 26 patients who underwent silicone oil removal developed recurrent RD (one patient on the first day, one in the $1^{\text {st }}$ month, and two in the third month). Of the 11 patients treated by giving C3F8, SF6, or air, 1 (9.1\%) patient given pure air developed recurrent detachment during the early follow-up. AS was achieved in 32 eyes (86.5\%), and FS was achieved in 17 eyes (45.9\%). The distribution of intraocular tamponade used is summarized in Table 4. Anatomical and functional success distribution is summarized in Table 5.

No statistically significant difference was observed in both AS and FS between the groups according to preoperative macular involvement $(p=0.98, p=0.36$ respectively), preoperative PVR presence $(p=0.61, p=0.14$ respectively), and whether PPV combined with CSB ( $p=0.97$, $p=0.24$ respectively). There was no statistical significance in both AS and FS between the types of the IOT used ( $p>0.05$ on both).

\section{DISCUSSION}

The risk of RD occurrence increases after cataract surgery. $\mathrm{RD}$ incidence is reported as $0.6 \%-1.7 \%$ in the first year after cataract surgery (11-13). Rowe et al. reported that the risk of retinal detachment was six times higher in those who underwent cataract surgery (14). Citirik et al. also stated that cataract surgery is the most common risk 
Table 5: Distribution of the anatomical and functional success

\begin{tabular}{|c|c|c|c|c|}
\hline Anatomical success & & $\begin{array}{c}\text { Yes, } n(\%) \\
\text { total: } 32 / 37(86.5 \%)\end{array}$ & $\begin{array}{c}\text { No, } n(\%) \\
\text { total: } 5 / 37(13.5 \%)\end{array}$ & ${ }^{++} p$ \\
\hline \multirow[t]{2}{*}{ Preop macular involvement } & Yes & $26(86.6 \%)$ & $4(13.4 \%)$ & 0.98 \\
\hline & No & $6(85.7 \%)$ & $1(14.3 \%)$ & \\
\hline \multirow[t]{2}{*}{ Preop PVR } & Yes & $8(80 \%)$ & $2(20 \%)$ & 0.61 \\
\hline & No & $24(88.8 \%)$ & $3(11.2 \%)$ & \\
\hline \multirow{2}{*}{$\begin{array}{l}\text { PPV with or } \\
\text { without CSB }\end{array}$} & With & $20 / 23(86.9 \%)$ & $3 / 23(13.1 \%)$ & 0.97 \\
\hline & Without & $12 / 14(85.7 \%)$ & $2 / 14(14.3 \%)$ & \\
\hline Functional success & & $\begin{array}{c}\text { Yes, } n(\%) \\
\text { total:17/37 (45.9\%) }\end{array}$ & $\begin{array}{c}\text { No, } n(\%) \\
\text { total: } 20 / 37(54.1 \%)\end{array}$ & ${ }^{++} p$ \\
\hline \multirow[t]{2}{*}{ Preop macular involvement } & Yes & $13(43.3 \%)$ & $17(56.7 \%)$ & 0.36 \\
\hline & No & $4(57.1 \%)$ & $3(42.9 \%)$ & \\
\hline \multirow[t]{2}{*}{ Preop PVR } & Yes & $7(70 \%)$ & $3(30 \%)$ & 0.14 \\
\hline & No & $10(37 \%)$ & $17(63 \%)$ & \\
\hline \multirow{2}{*}{$\begin{array}{l}\text { PPV with or } \\
\text { without CSB }\end{array}$} & With & $11 / 23(47.8 \%)$ & $12 / 23(52.2 \%)$ & 0.24 \\
\hline & Without & $6 / 14(42.8 \%)$ & $8 / 14$ (47.2\%) & \\
\hline
\end{tabular}

++Fisher's Exact and Chi-Square test between the groups in terms of the macular involvement, PVR presence, and whether PPV was combined with CSB; PVR: Proliferative vitreoretinopathy; CSB: Circumferential scleral buckling; preop: preoperative

factor for RRD, and $20-40 \%$ of RD patients had a history of cataract surgery (15). In our study, the time between cataract surgery and RD formation was an average of 15.5 months, and this period has been reported as 9.616 months in the literature $(16,17)$. In our study, $13.2 \%$ of patients had high myopia as the additional risk in pseudophakic RD etiology. Cankurtaran et al. also stated that if axial length is greater than $26 \mathrm{~mm}$, the risk of pseudophakic RD is four times higher (18).

In our study, there was a lack of lens capsule integrity in preoperative $29 \%$ of patients. RD had developed with an average of 11.7 months after in the ruptured capsules. Like us, Citirik et al. also stated the importance of the posterior capsule integrity for pseudophakic RD etiology (15).

In pseudophakic RD, PPV is superior to scleral procedures; since PPV ensures that the vitreous opacities are cleaned, and subretinal fluid is drained in a controlled manner. Also, tears in the periphery can be found more easily. Moreover, there is no a clear crystalline lens and an accommodation capacity that should be protected in pseudophakic eyes (19). During the follow-up, 4 (15.4\%) of the 26 patients who underwent silicone oil removal developed recurrent RD. It has been reported that the success rates of PPV alone and combined with CSB are between $88 \%$ and $100 \%$ (20-23). Bartz-Schmidt et al. reported that $94 \%$ AS with primary PPV achieved $100 \%$ with secondary PPV in pseudophakic RD (21). The AS ratio (86.5\%) of primary PPV in our study is consistent with the literature. Dang Burgener et al. reported no difference in success rates and recurrences between primary PPV and PPV with CSB (19). Similarly, Kessner et al. stated no significant differences between both treatments in AS and FS rates for pseudophakic RD. We also observed no statistically significant difference (24). However, Joseph et al. reported better AS for PPV with CSB (92\%) than PPV alone (84\%), and reported similar visual outcomes (25).

Figueroa et al. reported that $6 / 12$ and above BCVA was in $23 \%$ of eyes with macular involvement and $84.5 \%$ of eyes without macular involvement (26). Campo et al. reported a $65 \%$ preoperative macular involvement and that only $4 \%$ of these cases achieved 0.4 or more BCVA levels; however, these BCVA levels were $79 \%$ in cases without macular involvement (22). They also reported AS and FS rates as $86 \%$ and $62 \%$ in eyes with preoperative macular involvement and $91 \%$ and $82 \%$ in eyes without. However, we did not notice any statistical difference between those with or without preoperative macular involvement in AS and FS. This may be attributed to the unbalanced distribution of the groups with and without preoperative macular involvement and high preoperative BCVA value of the patients without involvement. Our AS rates are consistent with the literature, but FS is lower than reported in the literature, which can be explained by the preoperative macular involvement in most of our patients (81\%). 
However, in the present study, $75.6 \%$ of the patients, visual acuity improved compared to preoperative BCVA, but only $45.9 \%$ achieved FS criteria.

Dang Burgener et al. reported that the most critical factor affecting the surgical outcome is PVR (19). Çakır et al. reported a negative correlation between PVR grade and improvement of BCVA (27). Nevertheless, we observed no statistically significant difference between the PVR groups. This result may be explained as follows: PPV technique provides better shaving of the vitreous base in aphakic or pseudophakic eyes, better visualization of the peripheral retina, cleaning the membranes and bands, and flattening the retina by performing retinectomy/retinotomy more comfortably. Also, in advanced stage PVR, performing additional CSB and using a silicone oil tamponade provide better contact of retinal and retinal pigment epithelium and may improve the surgery results.

Temporary IOP elevation after PPV is a common complication, but it is rarely permanent. The increased IOP was reported $17.9 \%-48 \%$ after PPV with or without CSB in pseudophakic RD treatment $(23,28,29)$. However, we observed an elevated IOP in $18.4 \%$ of patients, which is consistent with the literature. Angle-closure glaucoma after CSB may occur due to a forward rotation and congestion of the ciliary body, and elevated IOP could be controlled with medical treatment and/or laser iridotomy. Intraocular gas tamponades may cause secondary angle-closure glaucoma by expansion. Pupil blocks may occur due to silicone oil tamponade in aphakic eyes, or synechia in pseudophakic eyes. Also, the emulsified silicone passing into the anterior chamber (AC) or inflammatory cells in $\mathrm{AC}$ may give rise to obstruction of trabeculae, and formation of glaucoma (30).

This study's weaknesses are its retrospective design, low number of cases, imbalance in the distribution of preoperative subgroups (i.e., presence of PVR, involvement of macula), used IOT diversity, and a relatively short follow-up period. However, its strength is that it gives an idea about PPV surgery with or without CSB in treating pseudophakic RD. Prospective, randomized controlled trials with large case series and extended follow-ups will provide more accurate data.

\section{CONCLUSION}

According to the present study, PPV with or without CSB is effective and safe in primary pseudophakic RD cases. These treatments provide good (86\%) anatomical success without being affected by preoperative PVR presence or macular involvement or the kind of endotamponade used. However, functional success may not always follow. The making-decision to surgical strategy (i.e., combining with CSB or the choice of IOT) should be made according to the eye's condition and RD's severity.
Ethics Committee Approval: This study was approved by the Ethics Committee of Bezm-i Alem University Faculty of Medicine (Date: 14.10.2009, No:10/12).

Informed Consent: Written consent was obtained from the participants.

Peer Review: Externally peer-reviewed.

Author Contributions: Conception/Design of Study- O.Ç., K.T.Ö.; Data Acquisition- Z.Y.; Data Analysis/InterpretationK.T.Ö., M.S.K.; Drafting Manuscript- Z.Y., K.T.Ö.; Critical Revision of Manuscript- K.T.Ö., M.S.K., O.Ç.; Final Approval and Accountability- Z.Y., M.S.K., O.Ç., K.T.Ö.

*Both $1^{\text {st }}$ and $2^{\text {nd }}$ authors (Zeynep Abdurrahmanoğlu and Kemal Turgay Özbilen) contributed equally.

Conflict of Interest: Authors declared no conflict of interest.

Financial Disclosure: Authors declared no financial support.

Etik Komite Onayı: Bu çalışma için etik komite onayı Bezm-i Alem Üniversitesi Tıp Fakültesi Etik Kurulu'ndan alınmıştır (Tarih: 14.10.2009, No:10/12).

Bilgilendirilmiş Onam: Katılımcılardan bilgilendirilmiş onam alınmıştır.

Hakem Değerlendirmesi: Dış bağımsız.

Yazar Katkıları: Çalışma Konsepti/Tasarım- O.Ç., K.T.Ö.; Veri Toplama- Z.Y.; Veri Analizi/Yorumlama- K.T.Ö., M.S.K.; Yazı Taslağı- Z.Y., K.T.Ö.; İçeriğin Eleştirel İncelemesi- K.T.Ö., M.S.K., O.Ç.; Son Onay ve Sorumluluk- Z.Y., M.S.K., O.Ç., K.T.Ö.

*Birinci ve ikinci yazar (Zeynep Abdurrahmanoğlu ve Kemal Turgay Özbilen) makaleye eşit katkıda bulunmuşlardır.

Çıkar Çatışması: Yazarlar çıkar çatışması beyan etmemişlerdir.

Finansal Destek: Yazarlar finansal destek beyan etmemişlerdir.

\section{REFERENCES}

1. Hagler WS. Pseudophakic retinal detachment. Trans Am Ophthalmol Soc 1982;80:45-63.

2. Wilkinson CP. Pseudophakic retinal detachments. Retina 1985;5(1):1-4. [CrossRef]

3. Boberg-Ans G, Henning V, Villumsen J, la Cour M. Long Term incidence of rhegmatogenous retinal detachment and survival in a defined population undergoing standardized phacoemulsification surgery. Acta Ophthalmol Scand 2006;84(5):613-8. [CrossRef]

4. Russell M, Gaskin B, Russell D, Polkinghorne PJ. Pseudophakic retinal detachment after phacoemulsification cataract surgery: Ten-year retrospective review. J Cataract Refract Surg 2006;32(3):442-5. [CrossRef]

5. Javitt JC, Tielsch JM, Canner JK, Kolb MM, Sommer A, Steinberg EP. National outcomes of cataract extraction. Increased risk of retinal complications associated with Nd:YAG laser capsulotomy. The Cataract Patient Outcomes Research Team. Ophthalmology 1992;99(10):1487-97; discussion 97-8. [CrossRef] 
6. American Academy of Ophthalmology, The repair of rhegmatogenous retinal detachments. Ophthalmic Procedure Assessment. Ophthalmology 1996;103(8):131324. [CrossRef]

7. Wilkinson CP. Visual results following scleral buckling for retinal detachments sparing the macula. Retina 1981;1(2):113-6. [CrossRef]

8. Burton TC. Recovery of visual acuity after retinal detachment involving the macula. Trans Am Ophthalmol Soc 1982;80:475-97.

9. Erkam N. Vitreoretinal cerrahide göz içi tampon maddeler. Medical Network Ophthalmology 1994(2):140-4.

10. Lois N, Wong D. Pseudophakic retinal detachment. Surv Ophthalmol 2003;48(5):467-87. [CrossRef]

11. Coonan P, Fung WE, Webster RG, Jr., Allen AW, Jr., Abbott RL. The incidence of retinal detachment following extracapsular cataract extraction. A ten-year study. Ophthalmology 1985;92(8):1096-101. [CrossRef]

12. Kraff MC, Sanders DR. Incidence of retinal detachment following posterior chamber intraocular lens surgery. J Cataract Refract Surg 1990;16(4):477-80. [CrossRef]

13. Smith PW, Stark WJ, Maumenee AE, Enger CL, Michels RG, Glaser BM, et al. Retinal detachment after extracapsular cataract extraction with posterior chamber intraocular lens. Ophthalmology 1987;94(5):495-504. [CrossRef]

14. Rowe JA, Erie JC, Baratz KH, Hodge DO, Gray DT, Butterfield $\mathrm{L}$, et al. Retinal detachment in Olmsted County, Minnesota, 1976 through 1995. Ophthalmology 1999;106(1):154-9. [CrossRef]

15. Citirik M. Pseudophakic retinal detachment; risk factors, pathogenesis, clinic and management. Current Retinal Journal 2020;4(3):153-9. [CrossRef]

16. Whang US JK, Park JM. Clinical evaluation of pseudophakic retinal detachment. J Korean Ophthalmol Soc 2001;42(7):991-6.

17. Ho PC, Tolentino FI. Pseudophakic retinal detachment. Surgical success rate with various types of IOLs. Ophthalmology 1984;91(7):847-52. [CrossRef]

18. Cankurtaran V ÖS, Khaleqi Z. Evaluation of risk factors causing retinal detachment after cataract surgery. MN Oftalmoloji 2020;27(1):39-43.

19. Dang Burgener NP, Petropoulos IK, Stangos AN, Pournaras CJ. Recurrence after primary vitrectomy for pseudophakic retinal detachment. J Fr Ophtalmol 2006;29(10):1149-55. [CrossRef]
20. Li X, Beijing Rhegmatogenous Retinal Detachment Study G. Incidence and epidemiological characteristics of rhegmatogenous retinal detachment in Beijing, China. Ophthalmology 2003;110(12):2413-7. [CrossRef]

21. Bartz-Schmidt KU, Kirchhof B, Heimann K. Primary vitrectomy for pseudophakic retinal detachment. $\mathrm{Br} \mathrm{J}$ Ophthalmol 1996;80(4):346-9. [CrossRef]

22. Campo RV, Sipperley JO, Sneed SR, Park DW, Dugel PU, Jacobsen J, et al. Pars plana vitrectomy without scleral buckle for pseudophakic retinal detachments. Ophthalmology 1999;106(9):1811-5; discussion 6. [CrossRef]

23. Devenyi RG, de Carvalho Nakamura H. Combined scleral buckle and pars plana vitrectomy as a primary procedure for pseudophakic retinal detachments. Ophthalmic Surg Lasers 1999;30(8):615-8. [CrossRef]

24. Kessner R, Barak A. Pseudophakic rhegmatogenous retinal detachment: combined pars plana vitrectomy and scleral buckle versus pars plana vitrectomy alone. Graefes Arch Clin Exp Ophthalmol 2016;254(11):2183-9. [CrossRef]

25. Joseph DP, Ryan EH, Ryan CM, Forbes NJK, Wagley S, Yonekawa $Y$, et al. Primary Retinal Detachment Outcomes Study: Pseudophakic Retinal Detachment Outcomes: Primary Retinal Detachment Outcomes Study Report Number 3. Ophthalmology 2020;127(11):1507-14. [CrossRef]

26. Figueroa MS, Lopez-Caballero C, Contreras I. Anatomical and functional outcomes of vitrectomy for the treatment of pseudophakic rhegmatogenous retinal detachment. Arch Soc Esp Oftalmol 2010;85(2):59-63. [CrossRef]

27. Çakır M, Çekiç O, Bayraktar Ş, Yılmaz ÖF. Surgical results of combined scleral encircling band and pars plana vitrectomy in pseudophakic retinal detachment. Retina-Vitreus 2007;15(4):249-52.

28. Dardenne MU, Gerten GJ, Kokkas K, Kermani O. Retrospective study of retinal detachment following neodymium:YAG laser posterior capsulotomy. J Cataract Refract Surg 1989;15(6):676-80. [CrossRef]

29. Ross WH. Pseudophakic retinal detachment. Can J Ophthalmol 1984;19(3):119-21.

30. Gedde SJ. Management of glaucoma after retinal detachment surgery. Curr Opin Ophthalmol 2002;13(2):103-9. [CrossRef] 